\title{
STUDI IN SILICO SINGLE CHAIN VARIABLE FRAGMENT (SCFV) SELEKTIF TERHADAP HORMON BASIC NATRIURETIC PEPTIDE (BNP)
}

\author{
Shabarni Gaffar*, Aga Adi Masyhuri, Yeni Wahyuni Hartati, Rustaman \\ Departemen Kimia, Fakultas Matematika dan Ilmu Pengetahuan Alam, Universitas Padjadjaran, Jln. Raya \\ Bandung-Sumedang km. 21 Jatinangor, Sumedang, Jawa Barat, 45363 \\ *Alamat Korespondensi: shabarni.gaffar@unpad.ac.id
}

\begin{abstract}
Abstrak: Basic natriuretic peptide (BNP) merupakan polipeptida yang terdiri dari 32 asam amino yang disekresikan oleh bilik jantung untuk merespon peregangan yang berlebihan pada sel otot jantung. Pengeluaran BNP dimodulasi oleh ion kalsium. BNP berpotensi untuk digunakan sebagai marker untuk meramalkan pasien yang mengalami gagal jantung. Anti BNP single chain variable fragment (Anti BNP SCFV) merupakan gabungan polipeptida antara daerah yang bervariasi pada rantai heavy (VH) dan rantai light (VL) dari immunoglobulin. Anti BNP SCFV akan berikatan dengan BNP melalui pengenalan antigen-antibodi yang biasanya berada pada daerah CDR (Complementary Determining Region) yang merupakan bagian dari SCFV. Tujuan penelitian ini adalah untuk mempelajari selektivitas docking SCFV yang diperoleh dari Protein Data Bank (PDB) dengan BNP berdasarkan parameter energi intermolekular secara in silico. SCFV terpilih dimodifikasi melalui penggantian asam amino yang berperan pada interaksi untuk mendapatkan SCFV yang lebih selektif terhadap BNP dengan energi interaksi intermolekular yang lebih rendah. Docking dilakukan menggunakan program Autodock 4.2.3. Visualisasi dilakukan menggunakan program Molegro Virtual Viewer. Hasil penelitian menunjukkan SCFV dengan ID-PDB 4OUO merupakan SCFV yang selektif terhadap BNP dengan energi intermolekular $-12,81 \mathrm{kkal} / \mathrm{mol}$, Ki 0,9712 M, namun energi ikatan yang positif: 17,33 kkal/mol. Penggantian asam amino arginin 116 menjadi histidin pada SCFV 4OUO memperlihatkan pengikatan yang lebih selektif terhadap BNP dengan energi intermolekul -13,66 kkal/mol, energi ikatan 16,47 kkal/mol, dan Ki 0,9726 M. Bagaimanapun, metode prediksi interaksi antara BNP dan SCFV perlu dikembangkan lebih lanjut untuk mendapatkan hasil yang lebih baik.
\end{abstract}

Kata kunci: BNP, SCFV, in Silico

\begin{abstract}
Basic natriuretic peptide (BNP) is a 32 amino acids polypeptide secreted by the chambers of the heart in response to excessive stretching of heart muscle cells. Excretion of BNP is modulated by calcium ions.BNP has the potential to be used as a marker topredict patients with heart failure. Anti BNP single chain variable fragment (Anti BNP-SCFV) is a combination of polypeptides of varying regions in the heavy chain (VH) and light chain (VL) of immunoglobulins. Anti BNP-SCFV will bind to BNP through the interaction of antibodyantigen in CDR (Complementary Determining Region) which is part of SCFV. The purpose of this research was to study the docking selectivity of SCFV from Protein Data Bank (PDB) with BNP based on intermolecular energy parameters. Selected SCFV was modified by replacement of some amino acids which important for interaction in the SCFV to get more selective SCFV to BNP with lower intermolecular interaction. Docking was done using Autodock 4.2.3. Visualization was done using Molegro Virtual Viewer. The result found that SCFV with PDB-ID $4 O U O$ was selective to BNP with the intermolecular energy of -12,81 kcal/mol, Ki 0,9712 M, but the binding energy was positive: 17,33 kcal/mol.. Replacement of amino acid arginine 116 to histidine in $4 O U O$ SCFV showed more selective binding with intermolecular energy -13,66kcal/mol, binding energy 16,47 $\mathrm{kcal} / \mathrm{mol}$, and $\mathrm{Ki} 0,9726 \mathrm{M}$. However, the method to predict interaction between BNP and SCFV need to developed to give a better result.
\end{abstract}

Keywords: $B N P, S C F V$, in silico

\section{PENDAHULUAN}

Molecular docking adalah suatu metode yang digunakan untuk memprediksi interaksi antara ligan (molekul kecil) dengan molekul besar seperti protein, enzim dan karbohidrat dengan tujuan untuk memprediksi kestabilan dan kespontanan interaksi yang dapat dilihat melalui energi bebas yang semakin kecil. Molecular docking sudah menjadi salah satu metode yang penting untuk penemuan obat baru dan untuk mempelajari interaksi antigen dan antibodi (Meng et al. 2011; Pedotti et al. 2011). Chen \& Shoichet (2009) menggunakan molecular docking untuk menyeleksi sejumlah senyawa inhibitor $\beta$ laktamase. Cherien et al. (2011) menggunakan molecular docking untuk mempelajari reaktivitas silang dari virus influenza H1N1. Podestà et al. (2014) juga menggunakan molecular docking untuk menyeleksi sejumlah SCFV yang berpotensi sebagai inhibitor racun organofosfat .

Sejak tahun 2011 jumlah penderita penyakit gagal jantung sudah mencapai satu juta kasus baru pertahunnya Roger et al. (2012). Salah satu metode untuk mendeteksi terjadinya gagal jantung pada pasien adalah dengan cara penentuan konsentrasi 
hormon natriuretik peptide tipe $\mathrm{B}$ (BNP) yang bermanfaat untuk diagnosis gagal jantung (Longenecker et al. 2009; Moe 2009). BNP merupakan polipeptida yang terdiri dari 32 asam amino yang disekresikan oleh bilik jantung untuk merespon tekanan yang berlebihan terhadap sel otot jantung (Saito 2010; Seferian et al. 2007). Konsentrasi BNP meningkat pada pasien yang mengalami disfungsi bilik jantung kiri dan berhubungan dengan tingkat keseriusan penyakit jantung (Saito 2010; Chung et al. 2006; Mueller et al. 2007; Tanfous et al. 2006). Oleh karena itu, antibodi terhadap BNP bermanfaat pada uji klinis atau untuk imaging kerusakan jantung.

Teknologi produksi antibodi telah berkembang kearah antibodi rekombinan sebagai molekul yang digunakan untuk diagnosis dan terapi (Leonard 2008). Sejumlah format antibodi rekombinan telah direkayasa untuk digunakan sebagai alat diagnosis. Salah satunya yang paling banyak dikaji adalah SCFV yang mengandung daerah yang bervariasi dari immunoglobulin, dihubungkan oleh asam amino penyambung (linker) yang bervariasi (Heo et al. 2006).

Maeng et al. (2012) menambahkan residu asam amino pada urutan SCFV sehingga struktur SCFV semakin panjang. Penambahan asam amino ini ternyata tidak mempengaruhi pengikatan SCFV terhadap BNP. Struktur tiga dimensi anti BNP SCFV belum tersedia pada Protein Data Bank, namun struktur SCFV yang berikatan dengan ligan lain sudah dilaporkan. Dalam rangka memperoleh struktur SCFV yang tepat untuk deteksi BNP, maka pada penelitian ini dilakukan docking sejumlah struktur SCFV dari PDB dengan BNP. Untuk mendapatkan SCFV dengan energi pengikatan yang lebih kecil maka perlu dilakukan penggantian asam amino pada struktur SCFV dengan harapan dengan adanya pergantian asam amino dapat membuat interaksi SCFV lebih selektif terhadap BNP.

\section{BAHAN DAN METODE}

\section{Penyiapan senyawa ligan untuk docking}

Struktur ligan (BNP) dibuat dengan software Marvin Sketch. Struktur BNP dibuat secara 2D, kemudian dirubah menjadi 3D. Struktur BNP 3D diminimalkan energinya menggunakan fitur MD pada Chem Office 3D dan disimpan dalam format pdb. Struktur ligan dengan format pdb diimpor ke software AutoDockTools, kemudian disimpan dengan format pdbqt.

\section{Penyiapan SCFV untuk docking}

Sebanyak 40 struktur SCFV diunduh dari Protein Data Bank kemudian dipisahkan dari ligannya dan diedit menggunakan AutoDockTools. File SCFV dari PDB dibuka menggunakan fitur Grid, kemudian disimpan dengan format pdbqt.

\section{Modifikasi SCFV}

Struktur SCFV dimodifikasi dengan mengganti asam amino yang berperan pada interaksi BNPSCFV. Urutan asam amino dari SCFV yang baru dari hasil modifikasi di upload ke SWISS-MODEL (http://swissmodel.expasy.org/) untuk mendapatkan struktur SCFV baru.

\section{Docking BNP dengan SCFV}

Sebelum docking dilakukan, disiapkan parameter grid untuk memberikan informasi tipe map yang akan dikomputasikan, lokasi, dan parameter pasangan energi potensial. Secara umum, satu map akan dihitung untuk setiap elemen pada ligan, ditambah map elektrostatik. File BNP dan SCFV dalam format pdbqt dibuka dan disimpan dalam format gpf, kemudian dijalankan dengan program Autogrid. Docking dilakukan dengan menggunakan program Autodock 4.2.3. Docking dilakukan dengan parameter algoritma genetik yang disimpan dalam format dpf. Autodock dijalankan dengan perintah \% autodock4 -p lig.macro.dpf -1 lig.macro.dlg\&. Hasil Autodock adalah berupa histogram dari beberapa eksperimen dan energinya yang dapat dilihat dalam file lig.macro.dlg. Hasil docking berupa $\Delta \mathrm{G}$ dikonversi menjadi Ki sehingga dapat diketahui nilai Ki dari kompleks BNP-Anti BNP SCFV.

\section{Visualisasi hasil docking}

Visualisasi dilakukan dengan menggunakan program Molegro Virtual Viewer. Hasil yang di visualisasi berupa interaksi antara BNP dengan SCFV. Kompleks yang dihasilkan juga dianalisis dengan plot Ramachandran menggunakan RAMPAGE web server (http://mordred.bioc. cam.ac.uk/ rapper/rampage.php )

\section{HASIL DAN PEMBAHASAN}

\section{Struktur 3 Dimensi SCFV dan BNP}

Struktur 3 dimensi SCFV dapat diperoleh dari Research Collaboratory for Structural Bioinformatics Protein Data Bank melalui alamat situs http://www.rscb.org/pdb/. Struktur kristal SCFV yang diambil dari PDB berjumlah empat puluh. Keempat puluh struktur kristal tersebut merupakan hasil penelitian dengan menggunakan kristalografi sinar X. Struktur SCFV yang diambil dari PDB adalah: IDPDB: 4OUO, 1NMC, 1MOE, 1MVU, 3NN8, 1NAM, 2UUD, 1A14, 1X9X, 4NKM, 1KTR, 4NKD, 2ZNX, 4NKO, 4P48, 4BUH, 104B, 3JUY, 1DZB, 3UMT, 3H3B, 2A9N, 3U6R, 2GJJ, 1XIW, 2OTU, 2YCI, 2YBR, 1P41, 4HOI, 4HOH, 4HOG, 4LAR, 4UT7, 4KV5, 4LAS, 4NIK, 3ABO, 4P49, 2A9M. Keempat puluh struktur SCFV dari PDB ini nantinya akan berperan sebagai makromolekul sedangkan BNP berperan sebagai ligan ketika proses docking. Struktur BNP untuk penelitian ini dibuat dengan menggunakan program Marvin sketch dan disimpan dengan format .pdb (Gambar 1).

\section{Docking SCFV dengan BNP}

Hasil docking antara BNP dan SCFV diperoleh nilai $\mathrm{Ki}$ yang besarnya tidak sama antara masing- 


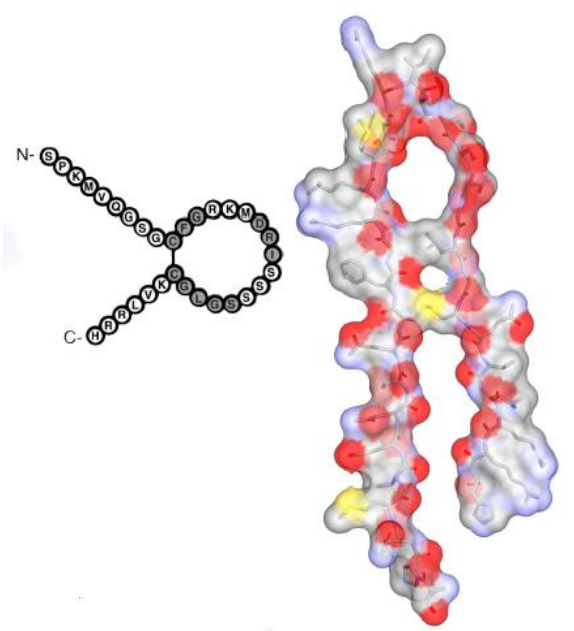

Gambar 1. Struktur dan urutan asam amino BNP.

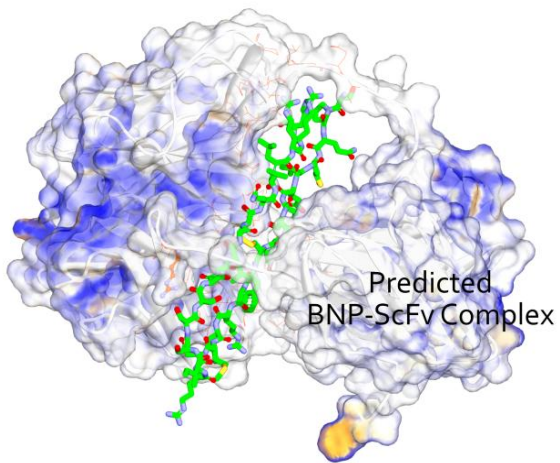

Gambar 2. Model interaksi antara BNP dan SCFV $4 \mathrm{OUO}$

masing molekul SCFV. Hasil docking antara BNP dan SCFV disajikan pada Tabel 1.

Nilai Ki dari hasil docking memiliki perbedaan yang tidak terlalu jauh, hal ini dikarenakan urutan asam amino dari SCFV yang didapatkan dari PDB memiliki homologi urutan yang tidak terlalu berbeda jauh (75-94\%), yang dibuktikan dengan alignment antara ke-empat puluh urutan SCFV menggunakan program aligment T-coffee (http://tcoffee.crg.cat /apps/tcoffee/do:expresso/) (data tidak diperlihatkan). Namun energi ikatan antara semua kompleks diperoleh nilai positif. Berdasarkan hasil docking diprediksi 4OUO merupakan SCFV yang selektif terhadap BNP jika dibandingkan dengan SCFV yang lain. SCFV 4OUO dapat membentuk interaksi yang lebih banyak dengan BNP jika dibandingkan dengan SCFV yang lain, model interaksi antara BNP dengan 4OUO dapat dilihat pada Gambar 2. Interaksi non kovalen antara BNP dan SCFV 4 OUO yaitu interaksi hidrogen dan elektrostatik diperlihatkan pada Gambar 3 dan 4. Interaksi ini berkontribusi terhadap nilai Ki dari SCFV 4 OUO dan BNP.

Untuk menunjukkan bahwa kompleks antara 4OUO dengan BNP merupakan kompleks yang memiliki kualitas yang baik adalah dengan menggambarkan kompleks 4OUO dengan BNP kedalam suatu plot Ramachandran. Melalui plot

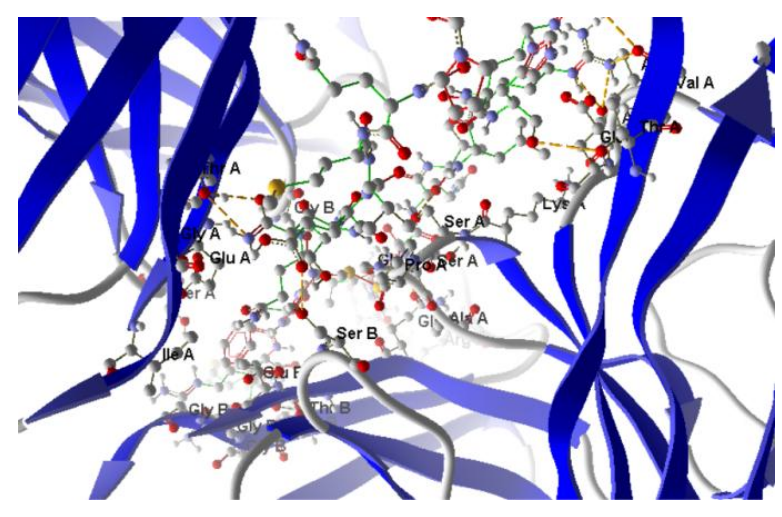

Gambar 3. Ikatan hidrogen antara BNP dan SCFV 4OUO. Asam amino SCFV 4OUO yang berkontribusi pada pembentukan ikatan hydrogen adalah Serin 42, Arginin 116, Glisin 127 dan Threonin 231

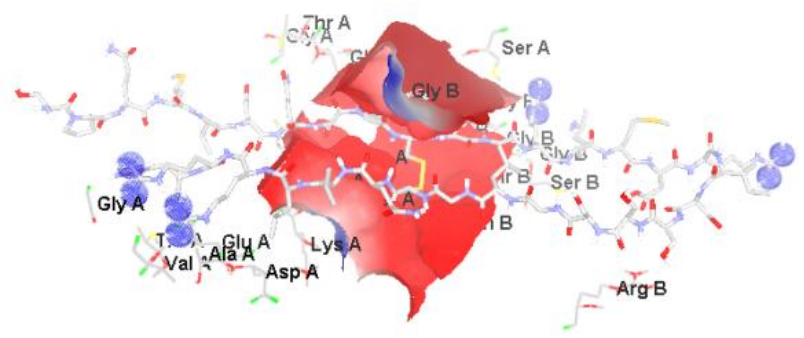

Gambar 4. Interaksi elektrostatik antara BNP dan SCFV $40 U O$

Ramachandran dapat diketahui suatu struktur protein mempunyai kualitas yang baik atau tidak. Caranya dengan melihat plot residu non glisin yang terletak pada wilayah sudut dihedral yangdilarang (disallowed regions). Glisin merupakan asam amino yang tidak mempunyai rantai samping sehingga sudut $\Phi$ dan $\psi$ nya dapat berada pada empat kuadran dari plot Ramachandran. Suatu struktur protein dinyatakan baik jika jumlah plot residu yang terdapat pada most favoured regions lebih dari $90 \%$ dan Rfactor tidak lebih dari $20 \%$. Untuk membuat plot Ramachandran komplek antara 4 OUO dengan BNP disimpan dalam bentuk .pdb kemudian digambarkan dengan bantuan server RAMPAGE. Server RAMPAGE merupakan group dari Crystallography \& Bioinformatics yang dikembangkan oleh University of Cambridge. Server RAMPAGE diakses melalui (http://mordred.bioc.cam.ac.uk/ rapper/ rampage.php). Plot Ramachandran antara SCFV 4OUO dengan BNP ditunjukkan pada Gambar 5.

Berdasarkan plot Ramachandran SCFV 4OUO dengan BNP didapatkan jumlah residu asam amino pada favour region sebesar 97,6 \% dan jumlah residu asam amino pada outlier region hanya sebesar $0,4 \%$. Hasil ini menunjukkan bahwa komplek ini memiliki kualitas yang baik. 
Tabel 1. Hasil docking BNP dengan SCFV

\begin{tabular}{|c|c|c|c|}
\hline No & Kompleks & $\begin{array}{c}\text { Energi ikatan } \\
(\mathrm{kkal} / \mathrm{mol})\end{array}$ & $\begin{array}{c}\mathrm{Ki} \\
\text { (Molar) }\end{array}$ \\
\hline 1. & 4OUO-BNP & 17,33 & 0,9712 \\
\hline 2. & 1NMC-BNP & 18,55 & 0,9692 \\
\hline 3. & 1MVU-BNP & 19,95 & 0,9669 \\
\hline 4. & 3NN8-BNP & 20,36 & 0,9662 \\
\hline 5. & 2UUD-BNP & 20,67 & 0,9657 \\
\hline 6. & 1NAM-BNP & 20,73 & 0,9656 \\
\hline 7. & 1MOE-BNP & 21,4 & 0,9645 \\
\hline 8. & 1A14-BNP & 22,62 & 0,9625 \\
\hline 9. & 4NKM-BNP & 23,75 & 0,9607 \\
\hline 10. & 2ZNX-BNP & 23,78 & 0,9607 \\
\hline 11. & 1KTR-BNP & 24,07 & 0,9602 \\
\hline 12. & 4NKO-BNP & 24,26 & 0,9599 \\
\hline 13. & 4NKD-BNP & 24,3 & 0,9598 \\
\hline 14. & 1X9Q-BNP & 25,04 & 0,9586 \\
\hline 15. & 4P48-BNP & 35,46 & 0,9419 \\
\hline 16. & 3JUY-BNP & 80,97 & 0,8723 \\
\hline 17. & 1DZB-BNP & 88,46 & 0,8613 \\
\hline 18. & 4UT7-BNP & 170,57 & 0,7498 \\
\hline 19. & 1P4B-BNP & 346,1 & 0,5575 \\
\hline 20. & 2A9N-BNP & 495,43 & 0,4333 \\
\hline 21. & 3U6R-BNP & 489 & 0,4380 \\
\hline 22. & 3H3B-BNP & 650 & 0,3338 \\
\hline 23. & 2YBR-BNP & 696 & 0,3089 \\
\hline 24. & 4HOI-BNP & 758 & 0,2782 \\
\hline 25. & 4HOG-BNP & 789 & 0,2640 \\
\hline 26. & 1P41-BNP & 1302 & 0,1111 \\
\hline 27. & 4HOH-BNP & 1315 & 0,1086 \\
\hline 28. & 4NIK-BNP & 1345 & 0,1033 \\
\hline 29. & 4KVS-BNP & 1365 & 0,09985 \\
\hline 30. & $3 \mathrm{ABO}-\mathrm{BNP}$ & 1421 & 0,09084 \\
\hline 31. & 4LAS-BNP & 1526 & 0,07609 \\
\hline 32. & 4P49-BNP & 1589 & 0,06841 \\
\hline 33. & 2A9M-BNP & 1598 & 0,06738 \\
\hline 34. & 4BUH-BNP & 1688 & 0,05788 \\
\hline 35. & 2GIJ-BNP & 1752 & 0,05196 \\
\hline 36. & 1XIW-BNP & 1813 & 0,04687 \\
\hline 37. & 2OTU-BNP & 1858 & 0,04344 \\
\hline 38. & 2YCI-BNP & 1912 & 0,03966 \\
\hline 39. & 4LAR-BNP & 1956 & 0,03682 \\
\hline 40. & 3UMT-BNP & 1978 & 0,03548 \\
\hline
\end{tabular}

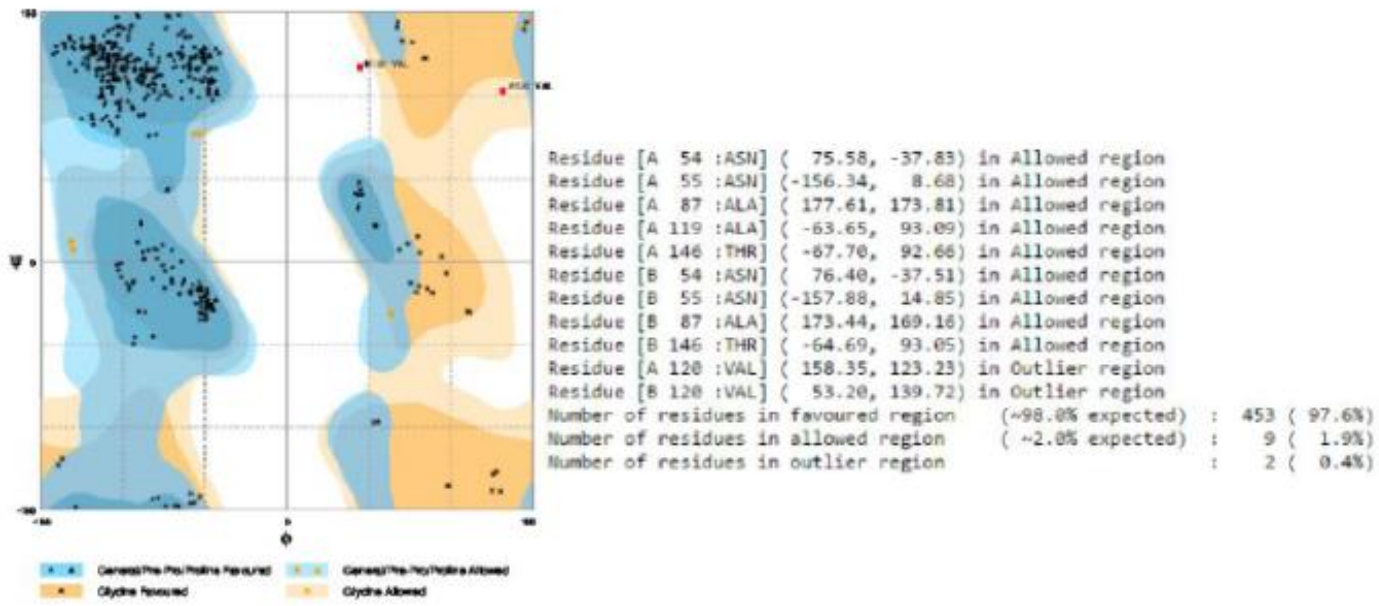

Gambar 5. Plot Ramachandran BNP dan SCFV 4OUO. Jumlah residu asam amino yang berada pada favoured region, allowed region dan outlier region adalah berturut-turut: 97,6\%, 1,9\% dan 0,4\%. 
Tabel 2. Hasil docking SCFV dengan penggantian asam amino dengan BNP

\begin{tabular}{|c|c|c|}
\hline Kompleks & $\begin{array}{c}\text { Binding Energy } \\
(\mathrm{kkal} / \mathrm{mol})\end{array}$ & $\begin{array}{c}\mathrm{Ki} \\
(\text { Molar }) \\
\end{array}$ \\
\hline Wild Type & 17.33 & 0.97120 \\
\hline R116H-BNP & 16.47 & 0.97260 \\
\hline S42T-BNP & 16.59 & 0.97240 \\
\hline S42C-BNP & 16.67 & 0.97230 \\
\hline S42Q-BNP & 16.78 & 0.97210 \\
\hline G127I-BNP & 16.79 & 0.97210 \\
\hline S42N-BNP & 16.84 & 0.97200 \\
\hline G127L-BNP & 17.03 & 0.97170 \\
\hline G127M-BNP & 17.07 & 0.97160 \\
\hline S42A-BNP & 17.15 & 0.97150 \\
\hline T231N-BNP & 17.16 & 0.97140 \\
\hline G127A-BNP & 17.2 & 0.97140 \\
\hline T231C-BNP & 17.22 & 0.97140 \\
\hline G127P-BNP & 17.25 & 0.97130 \\
\hline S42Y-BNP & 17.33 & 0.97120 \\
\hline R116K-BNP & 17.35 & 0.97110 \\
\hline T231S-BNP & 17.47 & 0.97090 \\
\hline T231Y-BNP & 17.47 & 0.97090 \\
\hline T231Q-BNP & 17.52 & 0.97090 \\
\hline T231A-BNP & 17.58 & 0.97080 \\
\hline G127V-BNP & 17.76 & 0.97050 \\
\hline
\end{tabular}

\section{Modifikasi SCFV 4OUO}

Dalam rangka mendapatkan struktur SCFV yang lebih selektif terhadap BNP, dilakukan modifikasi dari struktur SCFV 4OUO. Modifikasi pada struktur 4OUO dilakukan dengan cara mengganti salah satu asam amino pada struktur 4 OUO dengan asam amino lain yang memiliki sifat yang mirip dengan asam amino yang akan diganti.

Barnes \& Gray (2003) menjelaskan bahwa pergantian asam amino yang memiliki sifat yang sama dengan asam amino yang akan diganti, tidak akan menyebabkan perbedaan sifat dari suatu protein sehingga masih mempertahankan sifat dari protein tersebut. Apabila asam amino yang akan diganti bersifat polar maka asam amino penggantinya juga bersifat polar, hal ini bertujuan agar kita bisa melihat pengaruh pergantian asam amino tanpa adanya perubahan sifat dari protein. Asam amino SCFV 4OUO yang diganti adalah adalah serin 42 (menjadi sistein/asparagin/glutamin, threonin/metionin), arginin 116 (menjadi histidin/lisin), Glisin 127 (menjadi alanin/isoleusin/leusin/prolin/valin) dan threonin 231 (menjadi sistein/asparagin/glutamin /serin/metionin). Alasan digantinya keempat residu tersebut adalah karena residu tersebut memiliki peranan yang sangat besar dalam interaksinya dengan
BNP. Keempat residu tersebut memiliki nilai ikatan hidrogen tinggi jika dibandingkan dengan residu lain yang berinteraksi dengan BNP. Jarak ikatan hidrogen antara asam amino serin 42, arginin 116, glisin 127 dan threonin 231 dengan BNP berturut turut adalah 2,7 $\AA, 2,9 \AA, 2,8 \AA, 3 \AA$.

Urutan asam amino dari SCFV yang baru dari hasil penggantian asam amino di upload ke SWISSMODEL (http://swissmodel.expasy.org/) untuk mendapatkan model struktur dari SCFV baru. Untuk menentukan apakah hasil penggantian asam amino memiliki pengaruh yang lebih baik atau tidak terhadap pembentukan kompleks SCFV-BNP maka nilai $\mathrm{Ki}$ kompleks SCFV-BNP hasil penggantian dibandingkan dengan kompleks SCFV-4OUO wild type sehingga dapat diketahui pengaruhnya (Tabel 2).

Berdasarkan hasil nilai Ki dari dua puluh macam SCFV baru, ternyata penggantian arginin 116 menjadi histidin memberikan nilai $\mathrm{Ki}$ yang lebih tinggi dibandingkan dengan wild type. Perubahan arginin menjadi histidin memberikan efek yang cukup besar pada interaksi dengan SCFV-BNP (energi ikatan 17,33 vs $16,47 \mathrm{kkal} / \mathrm{mol}$ ). Hal ini kemungkinan disebabkan ukuran histidin yang lebih kecil dibandingkan arginin sehingga membuat struktur SCFV menjadi agak terbuka dan 


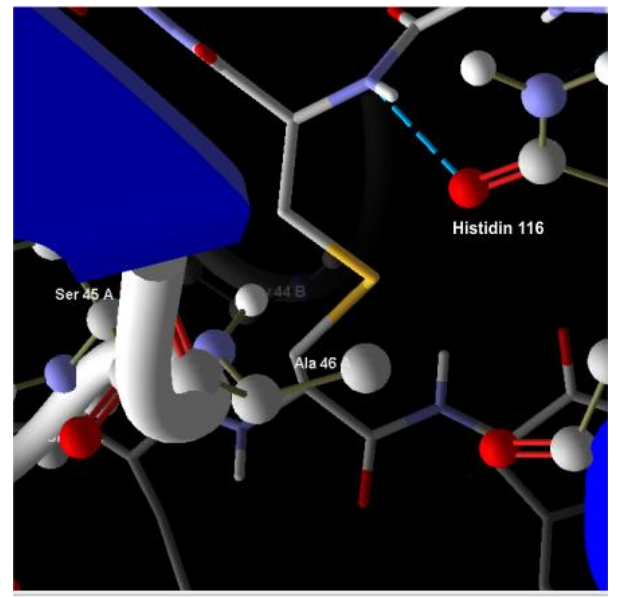

Gambar 6. Model ikatan hidrogen antara histidin 116 dengan BNP

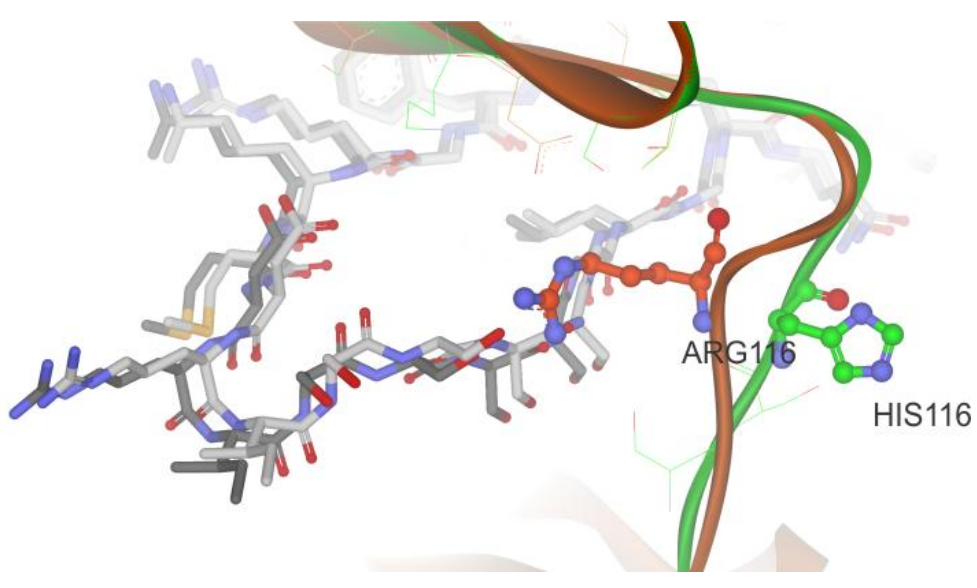

Gambar 7. Perbandingan struktur SCFV dengan residu arginin 116 Wild Type dengan histidin 116 hasil modifikasi

memungkinkan BNP untuk bisa masuk ke dalam struktur SCFV. Gambar 6 menunjukkan ikatan hidrogen antar histidin hasil modifikasi dengan BNP yang memiliki jarak ikatan hidrogen sebesar 3,1 A. Perbandingan antara wild type dan hasil modifikasi pada residu arginin diganti dengan histidin ini dapat dilihat pada Gambar 7

Untuk menguji apakah struktur SCFV yang baru ini memiliki konformasi yang stabil maka dilakukan analisis dengan plot Ramachandran (Gambar 8). Berdasarkan plot Ramachandran didapatkan jumlah residu asam amino yang berada pada daerah yang diperbolehkan sebesar 97,4 \% dan jumlah residu pada daerah yang dilarang hanya sebesar $0,65 \%$, hal ini menunjukkan bahwa struktur komplek ini memiliki kualitas yang baik. Hampir tidak ada perbedaan antara struktur plot Ramachandran wild type dengan $\mathrm{R} 116 \mathrm{H}$, hal ini dimungkinkan karena struktur SCFV yang dimodifikasi hanya satu asam amino sehingga tidak mempengaruhi struktur umum dari SCFV. Apabila dari struktur SCFV wild type banyak dilakukan perubahan maka sangat mungkin hasil dari plot Ramachandran ini akan sangat berbeda jika dibandingkan dengan wild type.
Pencarian struktur SCFV yang dapat digunakan untuk deteksi BNP dimulai dari pencarian struktur 3D SCFV pada Protein Data Bank (www.rcsb.org/pdb). Penggunaan SCFV untuk deteksi BNP lebih disukai dibanding immunoglobulin karena ukurannya yang lebih kecil. Hasil docking dari struktur kristal SCFV dengan 40 macam ID PDB terhadap BNP memperlihatkan SCFV 4OUO merupakan kandidat SCFV yang paling unggul ditinjau dari energi intermolekul, energi ikatan dan Ki. Analisis plot Ramachandran juga menunjukkan bahwa 97,6\% residu asam amino berada pada most favoured region. Akan tetapi nilai energi ikatan yang positif menunjukkan interaksi yang tidak spontan.

Penggantian asam amino arginin 116 menjadi histidin memberikan energi ikatan yang lebih kecil namun $\mathrm{Ki}$ yang lebih besar dibandingkan dengan wild type. Perubahan arginin menjadi histidin memberikan efek pada interaksi dengan SCFV-BNP, disebabkan karena ukuran histidin yang lebih kecil dibandingkan arginin sehingga membuat struktur SCFV menjadi agak terbuka dan memungkinkan BNP untuk bisa masuk ke dalam struktur SCFV. 


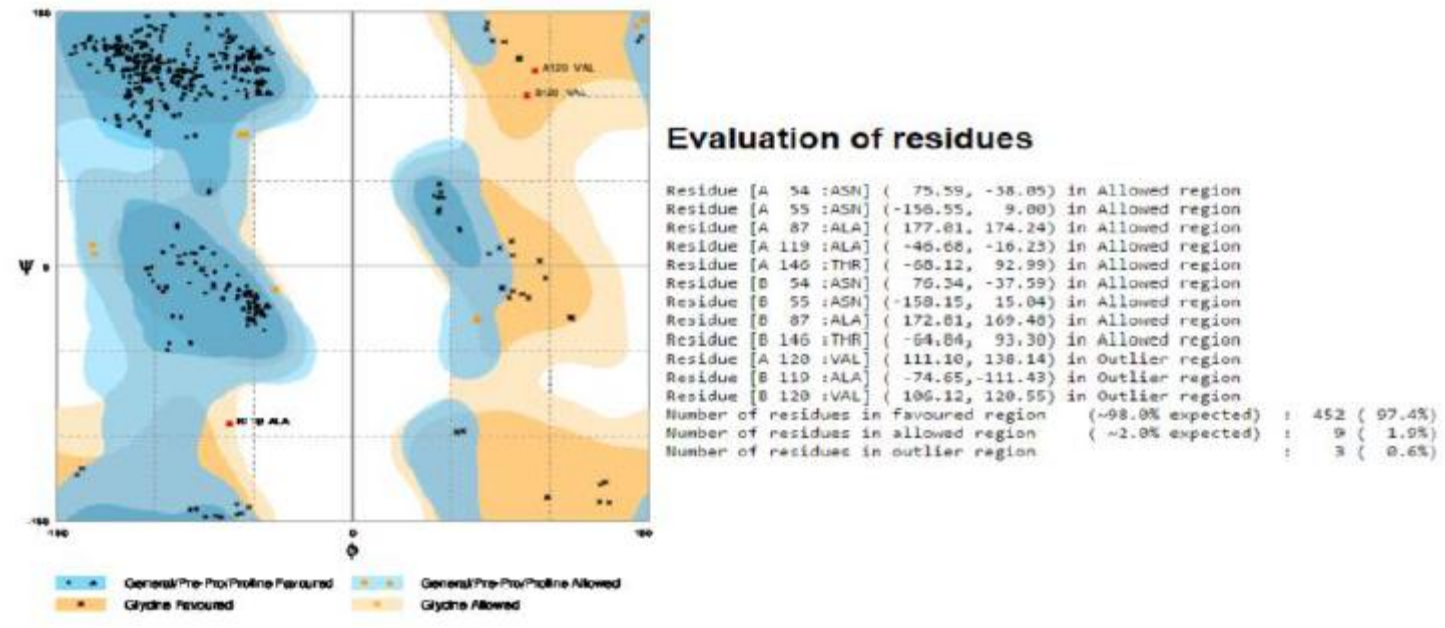

Gambar 8. Plot Ramachandran komplek SCFV R116H-BNP. Jumlah residu asam amino yang berada pada favoured region, allowed region dan outlier region adalah berturut-turut: 97,4\%, 1,9\% dan 0,6\%.

Penelitian ini belum bisa membuktikan apakah asam-asam amino pada SCFV yang berinteraksi dengan BNP berada pada daerah CDR, sehingga penelitian lebih lanjut diperlukan untuk memastikan asam amino yang berada pada daerah CDR.

Bagaimanapun, penelitian ini menunjukkan bahwa energi bebas antara BNP dengan SCFV bernilai positif. Secara termodinamika, interaksi antara keduanya tidak berjalan secara spontan. Pengembangan metode komputasi lebih lanjut perlu dilakukan untuk dapat memprediksi interaksi BNPSCFV secara lebih baik dan akurat, atau struktur SCFV yang lebih tepat.

\section{KESIMPULAN}

Hasil docking keempat puluh struktur SCFV yang diperoleh dari PDB terhadap BNP diperoleh SCFV 4OUO sebagai SCFV yang memiliki interaksi non kovalen yang paling kuat terhadap BNP. Penelitian lebih lanjut perlu dilakukan untuk mempelajari interaksi BNP terhadap SCFV pada daerah CDR.

\section{DAFTAR PUSTAKA}

Barnes, M.R. (2003). Bioinformatics for Geneticists. New York: John Wiley \& Sons.

Chen, Y. \& Shoichet, B.K. (2009) Molecular docking and ligand specificity in fragment-based inhibitor discovery. Nature Chemical Biology. 5(5): 358-364.

Cherien, S., Hil, P. \& Mishra, A.C. (2011) Antigenantibody docking reveals the molecular basis for cross-reactivity of the 1918 and 2009 Influenza A/H1N1 pandemic viruses. Bioinformation. 6(1): 35-38.

Chung, T., Sindone, A., Foo, F., Dwyer, A., Paoloni, R., Janu, M.R., Wong, H., Hall, J. \& Freedman, S.B. (2006). Influence of history of heart failure on diagnostic performance and utility of B-type natriuretic peptide testing for acute dyspnea in the emergency department. American Heart Journal. 152(5): 949-955.

Heo, M.A., Kim, S.H., Kim, S.Y., Kim, Y.J., Chung, J., Oh, M.K. \& Lee, S.G. (2006). Functional expression of single-chain variable fragment antibody against c-Met in the cytoplasm of Escherichia coli. Protein Expression and Purification. 47(1): 203-209.

Leonard G.P. (2008). Molecular engineering and design of therapeutic antibodies. Current Opinion in Immunology. 20(4): 460-470

Longenecker, K.L., Ruan, Q., Fry, E.H., Saldana, S.C., Brophy, S.E., Richardson, P.L. \& Tetin, S.Y. (2009). Crystal Structure and thermodynamic analysis of diagnostic mab 106.3 complexed with BNP 5-13 (C10A). Proteins: $\quad$ Structure, Function, and Bioinformatics. 76(3): 536-547.

Maeng, B.H., Choi, J., Sa, Y.S., Shin, J.H. \& Kim, Y.H. (2012) Functional expression of recombinant anti-BNP SCFV in methylotrophic yeast Pichia pastoris and application as a recognition molecule in electrochemical sensors. World Journal of Microbiology \& Biotechnology. 28(3): 1027-1034.

Meng, X.Y., Zhang, H.X., Mezei, M. \& Cui, M. (2011). Molecular docking: a powerful approach for structure-based drug discovery. Current Computer - Aided Drug Design. 7(2): 146-157.

Moe, G.W. (2006). B-type natriuretic peptide in heart failure. Current Opinion in Cardiology. 21(3): 208-214.

Mueller, C., Breidthardt, T., Laule-Kilian, K., Christ, M. \& Perruchoud, A.P. (2007) The integration of BNP and NT-proBNP into clinical medicine. Swiss Medical Weekly. 137(1-2): 4-12.

Pedotti, M., Simonelli, L., Livoti, E. \& Varani, L. (2011). Computational docking of antibodyantigen complexes, opportunities and pitfalls 
illustrated by Influenza Hemagglutinin. International Journal of Molecular Sciences. 12(1): 226-251.

Podestà, A., Rossi, S., Massarelli, I., Carpi, S., Adinolfi, B., Fogli, S., Bianucci, A.M. \& Nieri, P. (2014) Selection of a human butyrylcholinesterase-like antibody single-chain variable fragment resistant to AChE inhibitors from a phage library expressed in E. coli. mAbs. 6(4): 1084-1093.

Roger, V.L., Go, A.S., Lioyd-Jones, D.M., Benjamin, E.J., Berry, J.D., Borden, W.B., Bravata, D.M., Dai, S., Ford, E.S., Fox, C.S., Fullerton, H.J., Gillespie, C., Hailpern, S.M., Heit, J.A., Howard, V.J., Kissela, B.M., Kittner, S.J., Lackland, D.T., Lichtman, J.H., Lisabeth, L.D., Makuc, D.M., Marcus, G.M., Marelli, A., Matchar, D.B., Moy, C.S., Mozaffarian, D., Mussolino, M.E., Nichol, G., Paynter, N.P., Soliman, E.Z., Sorlie, P.D., Sotoodehnia, N., Turan, T.N., Virani, S.S., Wong, N.D., Woo, D. \& Turner, M.B. (2012). Heart disease and stroke statistics - 2012 update: a report from the American Heart Association. Circulation. 125(1): e2-e220.

Saito, Y. (2010) Roles of atrial natriuretic peptide and its therapeutic use. Journal of Cardiology. 56(3): 262-270.

Seferian, K.R., Tamm, N.N., Semenov, A.G., Mukharyamova, K.S., Tolstaya, A.A., Koshkina, E.V., Kara, A.N., Krasnoselsky, M.I., Apple, F.S., Esakova, T.V., Filatov, V.L. \& Katrukha, A.G. (2007). The brain natriuretic peptide (BNP) precursor is the major immunoreactive form of BNP in patients with heart failure. Clinical Chemistry. 53(5): 866873.

Tanfous, N.G.B., Kallel, H., Jarboui, M.A. \& Fathallah, D.M. (2006) Expression in Pichia pastoris of a recombinant SCFV form of MAb 107, an anti human CD11b integrin antibody. Enzyme and Microbial Technology. 38(5): 636642. 